\section{Election of IUPAC Officers}

and Bureau Members-Call for

\section{Nominations}

\section{t its assembly in Istanbul, Turkey, on Wednesday 14 and Thursday 15 August 2013, the IUPAC Council will be asked to elect a vice president and members of the Bureau to fulfill the vacancies cre- ated by retiring members. IUPAC National Adhering Organizations are invited to submit nominations no later than 13 June 2013.}

On 1 January 2014 Mark Cesa (USA), vice president and president-elect of IUPAC, will become president. Kazuyuki Tatsumi (Japan), current president, will become past president and remain an officer and a member of the Bureau for a period of two years, while Nicole Moreau (France), current past president, will retire. Secretary General René Deplanque (Germany) was elected to a four-year term 2012-2015 and continues his service for two more years. Treasurer John Corish (Ireland) who was re-elected for a four-year term 2012-2015, continues his service for two more years.

In addition, there are this year six vacancies for Elected members of the Bureau. Elected members are elected to a four-year term, and are eligible for re-election to a second four-year term. No National Adhering Organization shall have more than one Elected member on the Bureau, and the principle of fair geographical representation of members shall be taken into account, as stipulated in IUPAC Statutes.

Elected members whose terms expire at the end of 2013:

- Colin Humphris (UK) (2010-2013), eligible for nomination

- Stanislaw Penczek (Poland) (2006-2009, 20102013)

- Elsa Reichmanis (USA) (2006-2009, 2010-2013)

- Maria Van Dam-Mieras (Netherlands) (20062009, 2010-2013)

- Itamar Willner (Israel) (2010-2013), eligible for nomination

- Qi-Feng Zhou (China) (2010-2013), eligible for nomination

The following are members whose terms continue to the end of 2015:

- $\quad$ Christopher M.A. Brett (Portugal) (2012-2015)

- Javier García-Martínez (Spain) (2012-2015)

- Ram Lamba (Puerto Rico) (2008-2011, 2012-2015)

- Natalia Tarasova (Russia) (2008-2011, 2012-2015)
In addition to the five officers and the ten Elected Members, the Bureau also includes the eight Division Presidents (each elected by each individual Division), and three ex officio members representing the Operational Standing Committee, i.e. the Committee and Chemistry Education (CCE), the Committee on Chemistry and Industry $(\mathrm{COCl})$ and CHEMRAWN, the CHEMical Research Applied to World Needs Committee.

IUPAC National Adhering Organizations are invited to submit nominations to the Secretary General at <secretariat@iupac.org> no later than 13 June 2013.

It is important for a vibrant organization that all vacant positions are filled after a fair and vigorous election process, so all nominations are encouraged. So, to make your voice heard, contact your National Adhering Organization and get involved.

\section{What Does the Bureau Do?}

The Bureau is established by the Council to act for the Union during intervals between meetings of the Council; it therefore fulfills important functions by ensuring continuity. The Bureau normally meets once a year. It consists of the officers (president, vice president, secretary general, treasurer, immediate past president), the division presidents and chairs of the operational standing committees, and 10 other members elected by the Council. The elections should also allow for a fair geographical representation. In principle, no member country should have more than one elected member on the Bureau.

The principal duties of the Bureau-as quoted in the Statutes (S7)-are as follows:

- to ensure the strict observance of Statutes and Bylaws

- to prepare the agenda for meetings of the Council and in particular to make provision for elections

- to make recommendations thereon to the Council

- to attend the meetings of the Council

- to implement the decisions of the Council and execute the program of the Union as directed by the Council

- to take steps to ensure that international congresses of pure and applied chemistry are held

- to take decisions about the holding of scientific meetings as proposed by the division committees

- to take all other steps necessary for the good conduct of the affairs of the Union

See the Statutes and Bylaws for details. 